\title{
Assessing the Water Quality Improvement of Sewage Effluent Passage in a Natural Wetland: A Case Study of Makhado Oxidation Ponds, South Africa
}

\author{
Shibambu CS and Gumbo JR
}

\begin{abstract}
Wetlands are known of their pollution reduction characteristics due to their flat topography and dense vegetation which capture pollutants on the settling sediments. This study was carried out in order to assess the Water Quality of wetland downstream of Makhado oxidation ponds and its potential effects on irrigation waters by determining the physical-chemical parameters and the nutrient levels. The water samples were collected the effluent discharge of Makhado oxidation ponds (upstream), the middle section of the wetland (midstream) and downstream of the wetland. The climate data for the study was also used assess the contribution to variation in the physical chemical parameters during their passage through the wetland. The physical parameters were tested were found the physical parameters are mostly outside the target water quality range of irrigation water set out by DWAF and are within the DWAF guidelines for discharge of wastewater. The wetland inflow and outflow $\mathrm{pH}$ results were in the range of $7.35-9.07$ and $7.30-8.55$ and the $\mathrm{pH}$ results were within to the Department of Water and Sanitation (DWS) guideline values for wastewater discharge. The wetland inflow and outflow electrical conductivity results were in the range of 87.8-1853 and $2.3-1431.0 \mu \mathrm{S} / \mathrm{cm}$ respectfully. The wetland inflow and outflow total dissolved solids results were in the range of 44.9-1186.0 and $2.0-793.0 \mathrm{mg} / \mathrm{l}$ respectfully. The wetland inflow and outflow turbidity results were in the range of 72-299 NTU and 3-275 NTU respectfully. The wetland inflow and outflow dissolved oxygen results were in the range of $0.2-96.6 \mathrm{mg} / \mathrm{l}$ and $0.2-201.0 \mathrm{mg} / \mathrm{l}$ and coincided with high rainfall in the months of November to March. The wetland inflow and outflow water temperature results were in the range of $18.6-28.8{ }^{\circ} \mathrm{C}$ and $18.1-28.3{ }^{\circ} \mathrm{C}$ respectfully and were influenced by air temperature. The content of the anions, chloride, nitrite, bromide, nitrate, sulphates and phosphates, downstream of the wetland were lower than the discharge point. This may indicate that wetland was reducing their anion levels. The nutrients (nitrates, nitrites and phosphates) and chloride were higher than the DWAF guidelines for discharge of wastewater. The anion analysis also suggests that the wetland is becoming a nutrient rich environment bringing forth risks of eutrophication. Nitrite concentrations did not conform to the South African Water Guidelines on target water quality ranges for irrigation
\end{abstract}

Manuscript received October 20, 2020. The University of Venda is acknowledged for their financial support for research study (S343). The climatic data was provided by the ARC-Institute of Soil, Climate and Water in Pretoria, South Africa.

Shibambu CS is with the Department of Water \& Sanitation Prof Jabulani Ray Gumbo is with the Department of Hydrology \& Water Resources, University of Venda water. The presence of nutrients in wetland may contribute to development of harmful algal blooms.

Keywords - Wetlands, Anions, harmful algal blooms, subsistence farming, water quality

\section{INTRODUCTION}

The quality of water resources in South Africa is increasingly becoming threatened by eutrophication problems with $35 \%$ of the total water storage being eutrophic or hypertrophic [1]. Although eutrophication is the natural process of water bodies' aging, it is mostly exacerbated by anthropogenic activities. Such activities include the introduction of nutrients rich materials into water bodies. Phosphorous and nitrogen are mostly the culprits when discussing the nutrients rich sediments in water resources [2]. Sources of these nutrients are both point and nonpoint sources. Point sources are those sources where pollutants find their ways into water resources via an identified point. Such sources may include storm water drainages, industrial effluents, feedlots and wastewater treatment works while non-point sources may include washed fertilizers from agricultural lands [3].

From a South African perspective, nutrient rich materials in wastewater treatment works (WWTW) alone are in higher concentration than in nonpoint sources [4]. Chamier et al. [4] indicate that in South Africa, only $7.4 \%$ of wastewater treatment works (WWTW) were awarded the green drop certification. About $92.6 \%$ of the South African WWTW may be said to be noncompliant and their continued operation raises the risks of eutrophication in South African freshwater resources. Progressive eutrophication triggers massive production of cyanobacteria blooms [5]. In South Africa, cyanobacteria blooms have become an increasing problem in water resources and the cyanotoxins impact negatively surface drinking water sources [6].

Makhado oxidation ponds receives its from wastewater from Makhado township and then further treat this wastewater. The final effluent is discharged into a natural wetland, dominated by reed plant Phragmites australis [2]. The main objective of the study was: to determine physical-chemical parameters of wastewater as it passes through the wetland and to assesses the impact of climate parameters (rainfall/air temperature) on the water quality through the wetland. 


\section{MATERIALS AND METHODS}

\section{A. The study area}

The three sampling points were selected to represent the effluent discharge (upstream) point, midstream point and the downstream point (Figure 1). The water samples were monthly collected for a period of twelve months starting from November 2013 until October 2014. At each point, on-site measurements of physical parameters were conducted, and three water samples collected for laboratory analysis for anions.

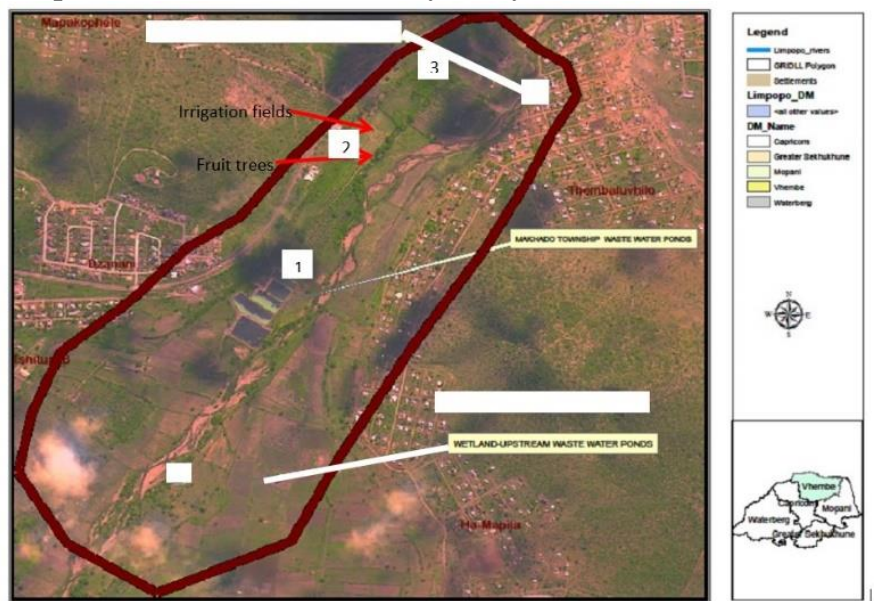

Fig. 1: Location of the study area showing location of the Makhado oxidation ponds discharging into 1 as upstream sample point, 2 middle stream and 3 as downstream sampling points

\section{B. On-site testing of physical parameters}

The Crison MM40 Multimeter was used to determine in triplicate, the levels of $\mathrm{pH}$, electrical conductivity (EC) total dissolved solids (TDS) and water temperature at each sample point. Before measurements were recorded, the Multimeter was calibrated according to the manufacturer's guide. The Orbeco TB200 portable turbidity meter was used to measure turbidity in triplicate. Before measurements were recorded, the turbidity meter was calibrated according to the manufacturer's guide. The Crison Oxi45 dissolved oxygen meter was used to measure dissolved oxygen in water in triplicate. The DO meter was calibrated according to the manufacturer's instruction.

\section{The anion analysis}

The anions $\left(\mathrm{F}^{-}, \mathrm{Cl}^{-}, \mathrm{Br}^{-}, \mathrm{NO}_{3}{ }^{2-}, \mathrm{PO}_{4}{ }^{3-}, \mathrm{SO}_{4}{ }^{2-}\right)$ were analyzed using Waters 432 Conductivity detector, coupled to a Waters 717 plus Auto sampler and an Agilent 1100 series binary pump as per APHA [7] at Stellenbosch University, South Africa.

\section{Climate data}

The climate data (rainfall, air temperature) was obtained from the ARC-institute of Soil, Climate and Water in Pretoria, South Africa. The climate data would assist in the data interpretation of observed variables.

\section{E. Data analysis}

The differences in water quality parameters between input (upstream) and output (midstream and downstream) for the wetland were determined using a paired samples t-test and single factor ANOVA. The statistical methods were implemented using Microsoft Excel 2010 and the level of significance for all tests was set to $\mathrm{p}<0.05$.

\section{RESULTS AND DISCUSSION}

\section{A. The general physical quality of water throughout the wetland}

The variations in each of the different physical water quality variable starting with discharge of effluent from Makhado township oxidation ponds which was the inflow into the wetland, through the middle section and outflow of the wetland are discussed. There was variation in the $\mathrm{pH}$ values of the water quality during the passage through the wetland (Figure 3).

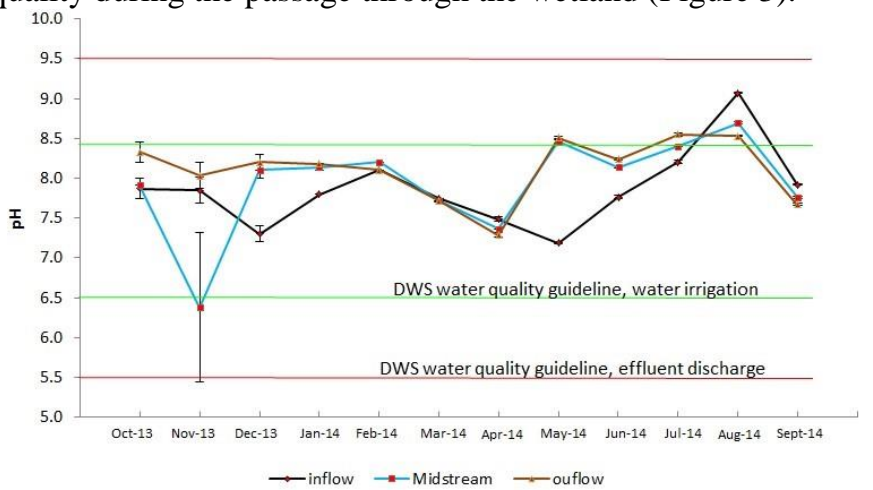

Fig. 3: Variation in $\mathrm{pH}$ levels through the wetland passage

The highest $\mathrm{pH}$ reading of 9.07 was recorded in August 2014 at the discharge point which is a point of effluent entry into the wetland. In the same month the midstream point, which is the point adjacent to the discharge point, recorded a $\mathrm{pH}$ value of 7.76 while the downstream point recorded 7.67. The lowest reading of 5.43 was recorded in November 2013 at the midstream point. At the same time the discharge recorded 7.6 while the downstream point recorded 8.22. According to the paired t-test analysis of the discharge and midstream sections $(p=0.21)$, midstream and downstream points $(p=0.28)$ and discharge and downstream sections $(\mathrm{p}=0.92)$. Therefore, there is no significant change in $\mathrm{pH}$ through the wetland. The wetland inflow and outflow $\mathrm{pH}$ results were in the range of $7.35-9.07$ and $7.30-8.55$ and the $\mathrm{pH}$ results were within to the Department of Water and Sanitation (DWS) guideline values for wastewater discharge [8] but slightly above the DWS guideline values for water irrigation [9]. The $\mathrm{pH}$ in excess of 8.5 will likely to affect crop foliar thus leading to reduced yield and or aesthetic value of the crop according to DWAF [9]. This may be to occur since most of irrigators obtain their irrigation water in the middle section of the wetland.

There was variation in the electrical conductivity (EC) values during the passage through the wetland (Figure 4). The discharge point recorded the highest value of EC at $1488 \mu \mathrm{S} / \mathrm{cm}$ while the midstream point recorded a value of $1802 \mu \mathrm{S} / \mathrm{cm}$ on the same month. The downstream point EC value of $965 \mu \mathrm{S} / \mathrm{cm}$ was lower as compared to the upstream points on the same month. According to the paired t-test analysis of the discharge and midstream sections $(p=0.49)$, midstream and downstream points $(\mathrm{p}=0.11)$ and discharge and downstream sections $(\mathrm{p}=$ 0.28 ). Therefore, there is no significant change in electrical conductivity through the wetland. 


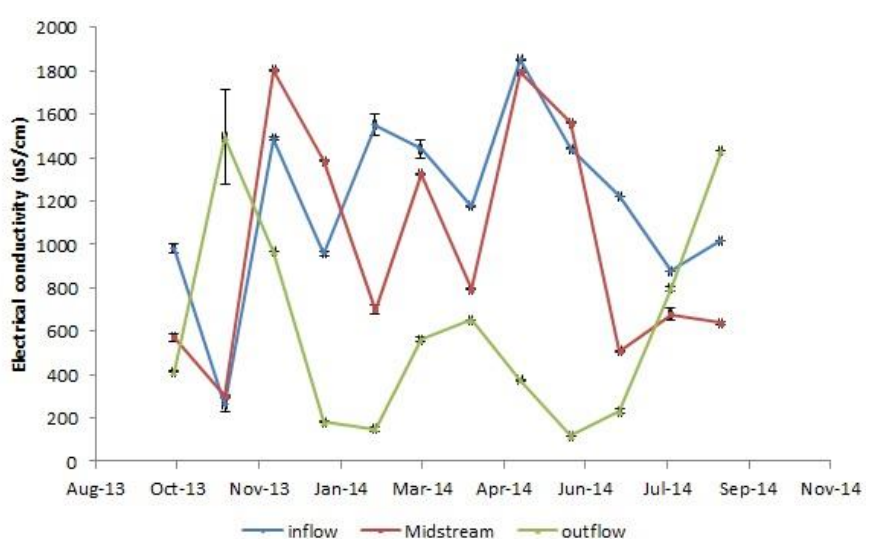

Fig. 4: Variation in electrical conductivity $(\mu \mathrm{S} / \mathrm{cm})$ through the wetland

The wetland inflow and outflow electrical conductivity results were in the range of $87.8-1853$ and $2.3-1431.0 \mu \mathrm{S} / \mathrm{cm}$ respectfully. The mean wetland inflow and outflow electrical conductivity results were $751.8 \pm 667.5$ and $448.6 \pm 0.518 .0$ $\mu \mathrm{S} / \mathrm{cm}$. Thus, the electrical conductivity results did conform to the Department of Water and Sanitation guidelines values for wastewater discharge of electrical conductivity range which should not exceed $2500 \mu \mathrm{S} / \mathrm{cm}$ [8].

There was variation in the total dissolved solids (TDS) values of the water quality during the passage through the wetland (Figure 4). The highest value of $1173.7 \mathrm{mg} / \mathrm{l}$ was recorded on the discharge point and lowest value of $2.0 \mathrm{mg} / 1$ was recorded on the downstream point. According to the paired $\mathrm{t}$-test analysis of the discharge and midstream sections $(\mathrm{p}=$ $0.63)$, midstream and downstream points $(\mathrm{p}=0.07)$ and discharge and downstream sections $(\mathrm{p}=0.22)$. Therefore, there is no significant change in total dissolved solids through the wetland.

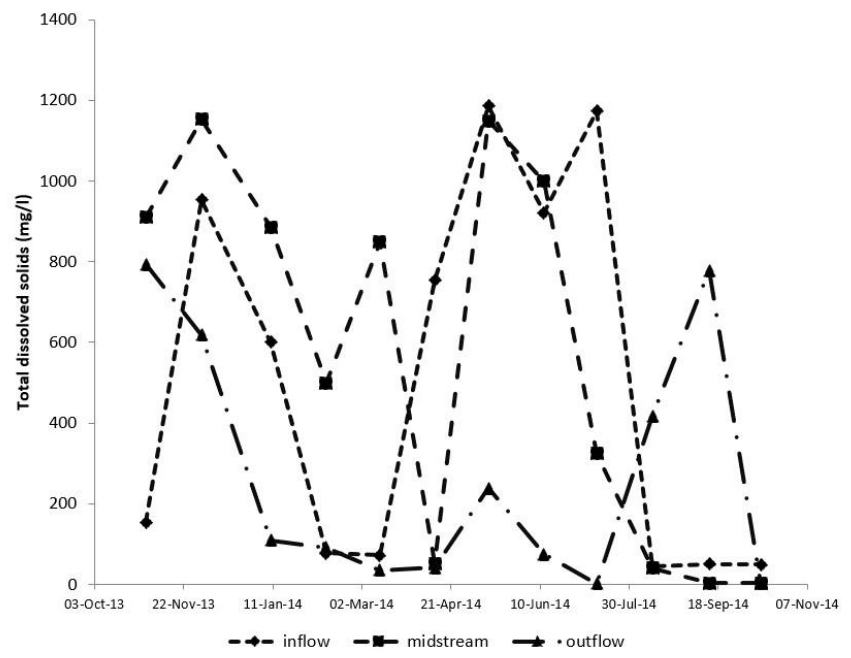

Fig. 5: Variation total dissolved solids $(\mathrm{mg} / \mathrm{l})$ through the wetland

The wetland inflow and outflow total dissolved solids results were in the range of 44.9-1186.0 and $2.0-793.0 \mathrm{mg} / \mathrm{l}$ respectfully. The mean wetland inflow and outflow total dissolved solids results were 503.2 \pm 474.3 and 267.2 \pm 304.8 $\mathrm{mg} / \mathrm{l}$. The total dissolved solids results did not conform to the Department of Water and Sanitation (DWS) guidelines values for wastewater discharge of total dissolved solids which should not exceed the maximum value of $25 \mathrm{mg} / \mathrm{l}$ [8]. Total dissolved solids were much higher than DWS acceptable standards. Some cyanobacteria have abilities to grow abundantly in salty water environment while freshwater environments with more trophic localities provide their desirable habitants [10].

There was variation in the turbidity values of the water quality during the passage through the wetland (Figure 6). The inflow point recorded the highest values of turbidity throughout the sampling period with a value of $299.17 \mathrm{mg} / \mathrm{l}$ in August 2014. The lowest values are observed on the downstream point with value of $2.74 \mathrm{mg} / \mathrm{l}$ in September 2014. According to the paired t-test analysis of the discharge and midstream sections $(\mathrm{p}=0.00)$, midstream and downstream points $(\mathrm{p}=0.63)$ and discharge and downstream sections $(\mathrm{p}=0.01)$. There was a significant change in turbidity levels between inflow and outflow indicating that the wetland was having a positive effect in reducing turbidity. The wetland inflow and outflow turbidity results were in the range of 72-299 NTU and 3-275 NTU respectfully (Figure 6). The mean wetland inflow and outflow turbidity results were $125 \pm 62$ NTU and $39 \pm 75$ NTU.

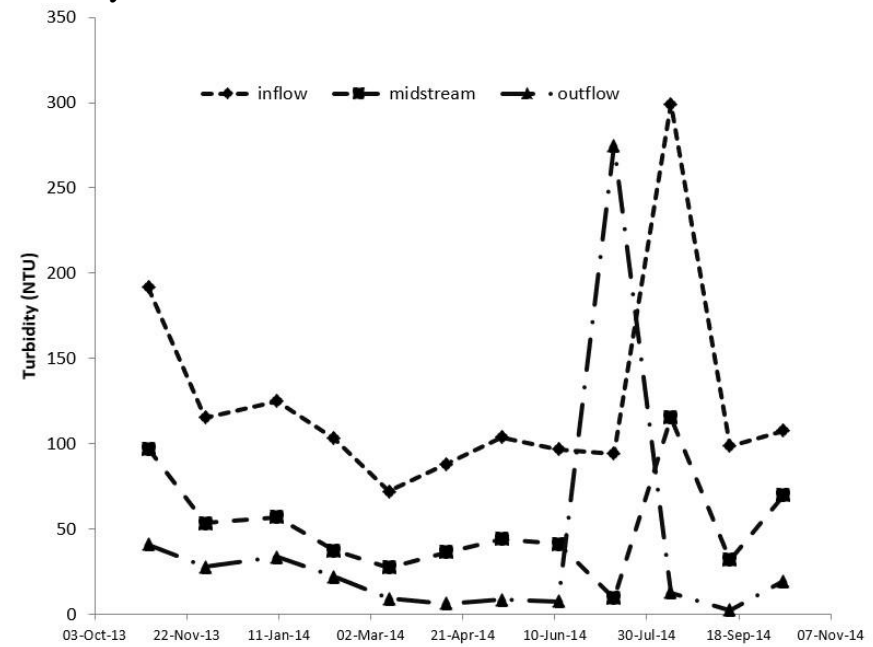

Fig. 6: Variation in Turbidity through the wetland

Most cyanobacteria are aerobic and autotrophic, and they can generate their own food from inorganic substances through sunlight in the presence of oxygen. They need carbon dioxide $\left(\mathrm{CO}_{2}\right)$, inorganic substances and light in a water environment to survive [10]. Turbidity measurements were high at the inflow points in which case sunlight penetration could be reduced thereby reducing the rate of cyanobacteria self-generation of food by affecting photosynthesis. Due to the canopy and high turbidity in the upstream point and midstream point, it is expected that the life processes of the cyanobacteria were affected.

There was variation in the dissolved oxygen (DO) values of the water quality during the passage through the wetland (Figure 7). The high DO levels that were experienced in the inflows also coincided with high rainfall in the months of November to March. The high DO was probably due oxygen enrichment from the rains that had fallen the previous days. According to the paired t-test analysis of the discharge and midstream sections $(\mathrm{p}=0.89)$, midstream and downstream points $(p=0.03)$ and discharge and downstream sections $(p=$ 
0.00). Therefore, there was a significant change in dissolved oxygen levels between inflow and outflow indicating that the wetland was having a positive effect in increasing the DO levels.

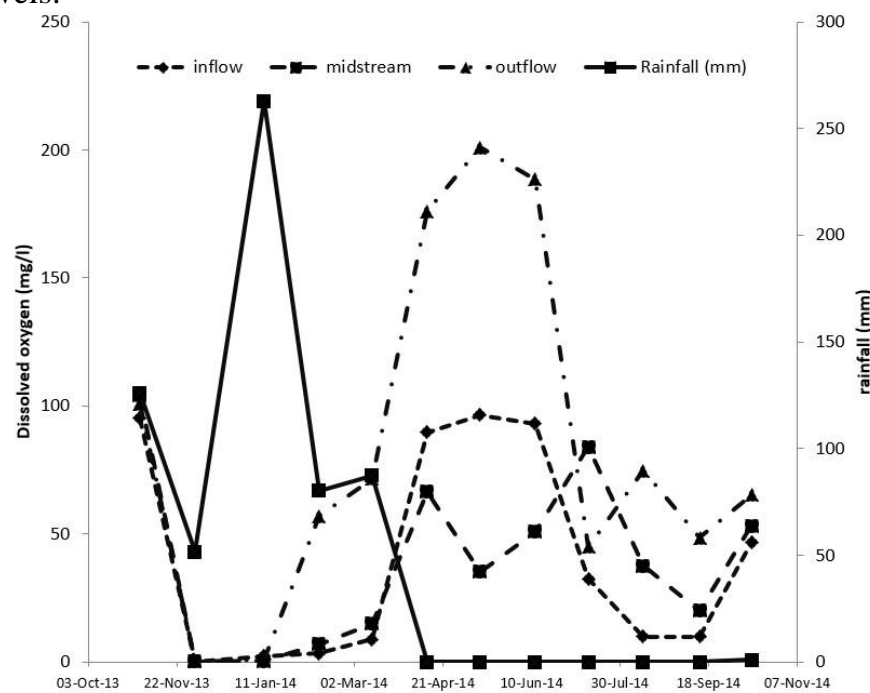

Fig. 7: Variation in dissolved oxygen $(\mathrm{mg} / \mathrm{l})$ concentration through the wetland

The wetland inflow and outflow dissolved oxygen results were in the range of $0.2-96.6 \mathrm{mg} / \mathrm{l}$ and $0.2-201.0 \mathrm{mg} / \mathrm{l}$ respectfully. The mean wetland inflow and outflow dissolved oxygen results were $40.8 \pm 41.3 \mathrm{mg} / \mathrm{l}$ and $85.8 \pm 68.3 \mathrm{mg} / \mathrm{l}$. The dissolved oxygen results did conform to the Department of Water and Sanitation guidelines values for wastewater discharge general limits of at least $75 \%$ at the inflow. However, at the outflow the values are above the minimum of the general limits [8]. The general limits require that DO should be at least $75 \%$ saturation and this is equal to $750 \mathrm{mg} / \mathrm{l}$. The presence of the cyanobacteria from the upstream points through to the midstream point may have contributed to the depletion of dissolved oxygen. However, DO levels are observed as increasing on the downstream point due to the absence of cyanobacteria.

There was variation in the water temperature values of the water quality during the passage through the wetland (Figure 8). The water temperature reached a maximum of $28.8^{\circ} \mathrm{C}$ at the inflow point in January 2014. The air temperature was also higher during the same month of January (Figure 8). According to the paired t-test analysis of the inflow and midstream sections $(\mathrm{p}=0.08)$, midstream and outflow points $(\mathrm{p}=0.02)$ and inflow and outflow sections $(\mathrm{p}=0.89)$. Therefore, there was no significant change in water temperature change in the wetland.

The air temperature also influenced the water temperature inflow, midstream and outflow sections of the wetland. According to the paired t-test analysis of the inflow and midstream sections $(p=0.00)$, midstream and outflow points $(\mathrm{p}=0.00)$ and inflow and outflow sections $(\mathrm{p}=0.00)$.

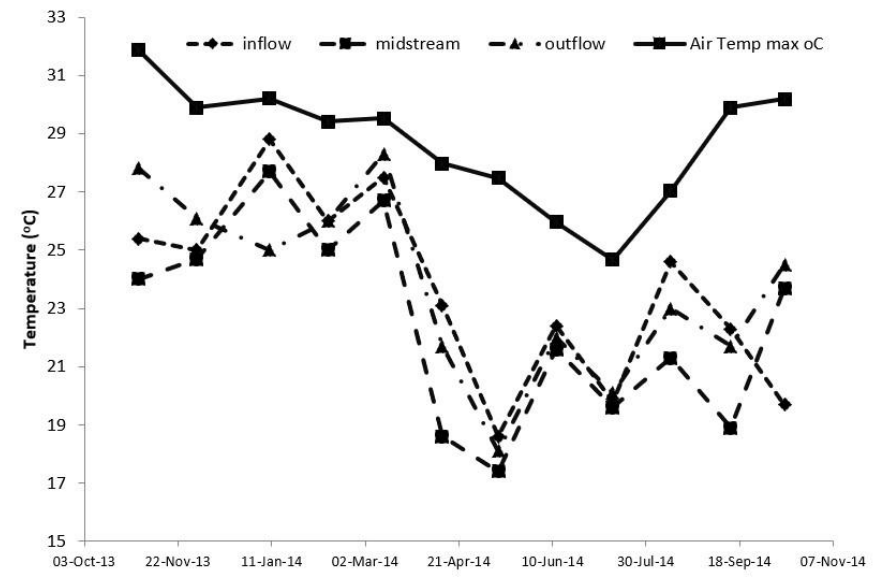

Fig. 8: Variation in water and air temperature $\left({ }^{\circ} \mathrm{C}\right)$ through the wetland

The wetland inflow and outflow water temperature results were in the range of $18.6-28.8{ }^{\circ} \mathrm{C}$ and $18.1-28.3^{\circ} \mathrm{C}$ respectfully. The mean wetland inflow and outflow water temperature results were $23.6 \pm 3.2{ }^{\circ} \mathrm{C}$ and $23.7 \pm 3.1{ }^{\circ} \mathrm{C}$. Thus, the temperature results were within to the Department of Water and Sanitation guidelines values for wastewater discharge of water temperature which shall not exceed $35{ }^{\circ} \mathrm{C}$ [8]. The water Temperatures in the wetland are recorded between $17^{\circ} \mathrm{C}$ and $28.8^{\circ} \mathrm{C}$, which are warmer temperatures. Cyanobacteria species grow well in temperatures ranging between $16{ }^{\circ} \mathrm{C}$ and $27{ }^{\circ} \mathrm{C}$ [11]. It can be deduced therefore that water temperatures of less than $16{ }^{\circ} \mathrm{C}$ are not favorable environments for the cyanobacteria. With warmer temperatures in the wetland, favorable conditions for the development and thriving of the cyanobacteria are provided for through the wetland.

\section{A. The general Anions of water quality throughout the wetland}

The variations in each of the different anions in water are discussed starting with discharge of effluent from Makhado township oxidation ponds which were the inflow into the wetland, through the middle section and outflow of the wetland. The anions analyzed are chloride, nitrite, bromide, nitrate, sulphates and phosphates.

\section{1) Chloride}

The highest value of chloride was recorded during September at $1707.1 \mathrm{ppm}$ at the discharge point while the lowest reading was recorded at $22.62 \mathrm{ppm}$ at the same point (Figure 9). The target water quality range for irrigation purposes is $\leq 100 \mathrm{ppm}$ [9] above which crops start to accumulate the chloride contents to toxic levels which affect the quality of the crops [9]. Mostly the chloride content did not conform to the DWAF limits accept only during May 2014 at the discharge point where it was recorded at $22.62 \mathrm{ppm}$. The following graph indicates the variations of chloride contents through the wetland (Figure 9) with the downstream chloride level being lower than the discharge point indicating the removal of chloride during its passage in the wetland. 


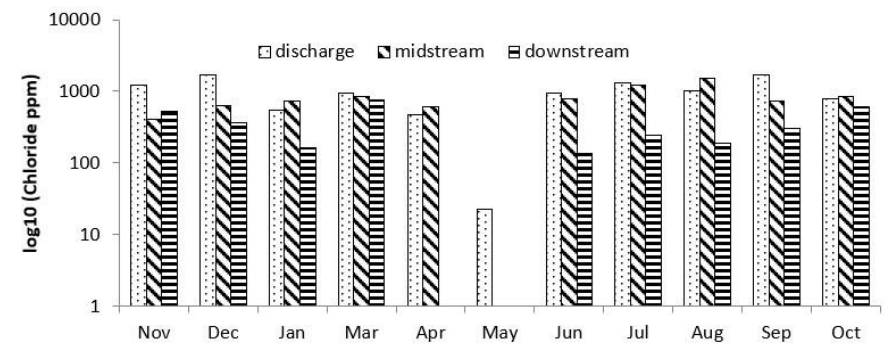

Fig. 9: The variation in chloride content through the wetland

The downstream point recorded 0 ppm of the chloride contents during April 2014 and May 2014 while the midstream recorded 0 ppm only during May 2014.

\section{1) Nitrite}

The Nitrite concentrations recorded higher levels above the recommended target water quality range (Figure 10). The highest value was recorded at discharge point at $2134.14 \mathrm{ppm}$ during September 2014 while the lowest value was recorded at $1.02 \mathrm{ppm}$ at the downstream point during February 2014. The following graph shows the variation in concentration in Nitrite through the wetland during the sampling period (Figure 10). Nitrite concentrations did not conform to the South African Water Guidelines on target water quality ranges for irrigation water.

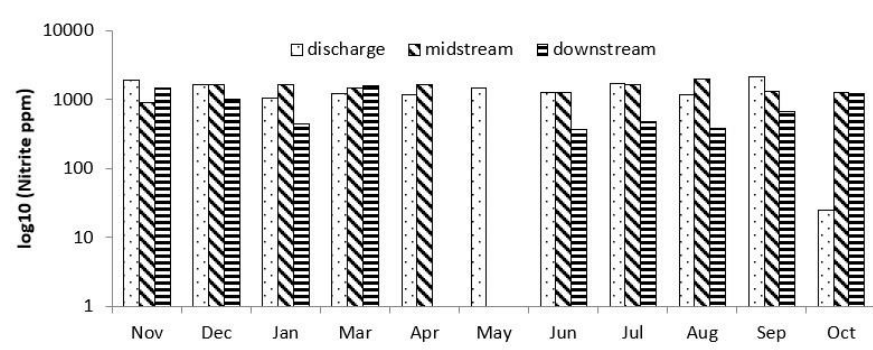

Fig. 10: The variation in Nitrite concentrations through the wetland

\section{1) Nitrate}

High levels of Nitrate were recorded through the wetland with the highest values recorded at $8715.66 \mathrm{ppm}$ recorded during May 2014 while the lowest reading was made at $167.73 \mathrm{ppm}$ during September 2014 (Figure 11). During the sampling period Nitrate variations did not conform to the DWAF limits set at $0.5 \mathrm{ppm}$ [9] on ten sampling events. But during other sampling runs, the nitrates levels were within the desired DWAF limits of nitrate concentrations. The following graph shows the variations in nitrate concentration through the wetland (Figure 11). The presence of nitrates in wetland may contribute to development of harmful algal blooms. Also, the presence nutrients in the wetland waters may be exploited by subsistence farmers for use in the irrigation plots that are located close to the wetland.

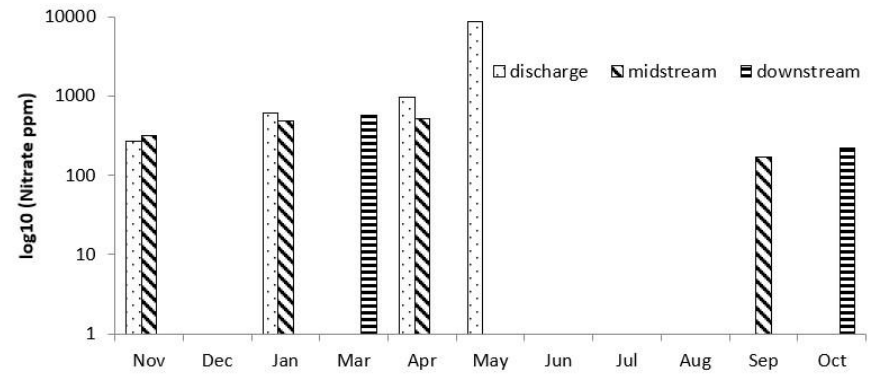

Fig. 11: The variation in Nitrate concentrations through the wetland

\section{1) Sulphate}

Sulphate ion has fertility benefit in irrigation water and toxicity is rarely a problem except only in very high concentration where it may interrupt the uptake of other nutrients [12]. The highest value of sulphate was recorded at $315.08 \mathrm{ppm}$ at the discharge point during May 2014 and the lowest value was recorded at $12.92 \mathrm{ppm}$ at the downstream point during July 2014 (Figure 12).

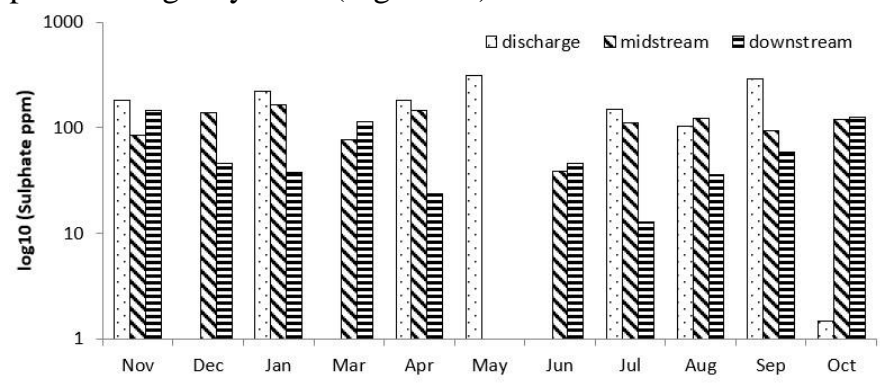

Fig. 12: The variation of Sulphate concentrations through the wetland

\section{1) Phosphate}

Phosphate is salts containing phosphorus which is commonly applied in irrigation as fertilizers. It provides crops with the energy to grow and has therefore not been limited in irrigation water. The South African water quality guidelines on irrigation water do not provide for the target water quality range since it is a requirement for plant growth. The following graph shows the variations in phosphate through the wetland during the sampling period (Figure 13). The highest value of phosphate was recorded during December at the midstream point at 996.27 ppm while the lowest was recorded at $34.29 \mathrm{ppm}$ during October at the downstream point. The presence of phosphate in wetland may contribute to development of harmful algal blooms. The presence nutrients in the wetland waters may be exploited by subsistence farmers for use in the irrigation plots that are located close to the wetland.

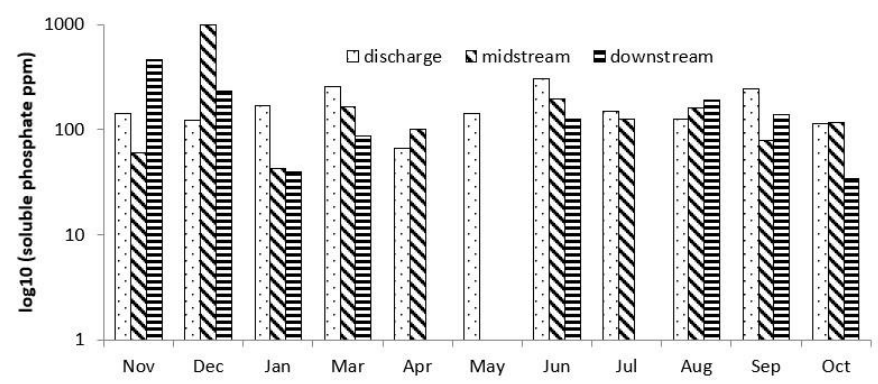

Fig. 13: The variation in Phosphate concentrations through the wetland 


\section{1) Bromide}

Bromide ion recorded $0 \mathrm{ppm}$ in concentrations from November 2013 until July 2014. From August 2014 it was recorded at $39.74 \mathrm{ppm}$ and increased to $63.59 \mathrm{ppm}$ during September 2014 and increased to $89.05 \mathrm{ppm}$ at the midstream point while the discharge point and the downstream point continued to record $0 \mathrm{ppm}$. The source of bromide may be the use of ammonium bromide used as a disinfectant in oxidation ponds [13] and or linked to the geology [14].

\section{CONCLUSION}

The majority of physical water quality parameters were within the target water quality range for effluent discharge into a water resource. The physical parameters were tested were found the physical parameters are mostly outside the target water quality range of irrigation water set out by DWAF and are within the DWAF guidelines for discharge of wastewater. The exceptions were with total dissolved solids which were higher than $25 \mathrm{mg} / \mathrm{l}$ guideline value. The anions were analysed by Ion Chromatography and showed spatial variation in content and seasonality. The nutrients (nitrates, nitrites and phosphates) and chloride were higher than the DWAF guidelines for discharge of wastewater. The anion analysis also suggests that the wetland is becoming a nutrient rich environment bringing forth risks of eutrophication. Nitrite concentrations did not conform to the South African Water Guidelines on target water quality ranges for irrigation water. The presence of nutrients in wetland may contribute to development of harmful algal blooms. Further research is required to assess the levels of cyanotoxins in wetland and how the aquatic macrophytes can bioaccumulate the cyanotoxins and source of bromide.

\section{ACKNOWLEDGMENT}

The University of Venda is acknowledged for their financial support for research study (S343). The climatic data was provided by the ARC-Institute of Soil, Climate and Water in Pretoria, South Africa.

\section{REFERENCES}

[1] Harding, W. R., Downing, T. G., Van Ginkel, C. E., \& Moolman, A. P. (2009). An overview of cyanobacterial research and management in South Africa post-2000. Water SA, 35(4), 479-484.

https://doi.org/10.4314/wsa.v35i4.76792

[2] Shibambu, C., Gumbo, J., \& Gitari, W. (2017). Field Study On Heavy Metal Removal In A Natural Wetland Receiving Municipal Sewage Discharge. International Journal of Sustainable Development and Planning, 12(1), 1-10. https://doi.org/10.2495/SDP-V12-N1-1-10

[3] Makhera, M. Gumbo, J. R. Chigayo, K. (2010). Monitoring of microcystin-LR in Luvhuvu River catchment: Implications for human health. African Journal of Biotechnology.10 (3), 406 - 411.

[4] Chamier, J, Oberholster, P., and Botha, A-M., (2012). Longitudinal pattern changes in water chemistry and phytoplankton downstream of the Riverview WWTP in the upper Olifants River. CSIR. South Africa https://doi.org/10.1016/j.ecohyd.2013.03.001

[5] Oberholster, P. J. Botha, A-M., Myburgh J. G. (2009). Linking climate change and progressive eutrophication to incidents of clustered animal mortalities in different geographical regions in South Africa. African Journal of Biotechnology. 8(21), 5825 - 5830 https://doi.org/10.5897/AJB09.1060

[6] Mokoena, M. M., Mukhola, M. S., \& Okonkwo, O. J. (2016). Hazard assessment of microcystins from the household's drinking water. Applied Ecology and Environmental Research, 14(3), 695-710. https://doi.org/10.15666/aeer/1403_695710

[7] American Public Health Association (APHA), (2008). Standard methods for the examination of water and wastewater, supplement. L. S. Clesceri (Ed.). 2008. Washington, DC: American Public Health Association]

[8] Department of Water Affairs (DWA), Annexure: General and Special Effluent Standards, Government Gazette 18 May 1984 no 9225. Regulation no. 99118 May 1984

[9] DWAF, (1996). South African Water quality guidelines (second edition). Volume 4: Agricultural use: Irrigation

[10] Muhetaer G, Asaeda T, Jayasanka SM, Baniya MB, Abeynayaka HD, Rashid MH, Yan H. Effects of Light Intensity and Exposure Period on the Growth and Stress Responses of Two Cyanobacteria Species: Pseudanabaena galeata and Microcystis aeruginosa. Water. 2020 Feb;12(2):407. https://doi.org/10.3390/w12020407

[11] Rai, S. V., \& Rajashekhar, M., (2014). Effect of pH, salinity and temperature on the growth of six species of marine phytoplankton. Journal of Algal Biomass and Utilization. 5(4):55-59

[12] Bauder T.A, Waskom R.M, Davis T.G, (2011). Crop Series Irrigation, No. 0506, Irrigation water quality criteria, Colorado State University, US Department of Agriculture and Colorado Counties Cooperating, USA

[13] Water Research Commission. Guide for Management of Waste Stabilisation Pond Systems in South Africa. WRC REPORT NO. TT 471/10, NOVEMBER 2010

[14] Lucht HL, Casey NH. Prevalence of bromide in groundwater in selected regions in South Africa. Water SA. 2019 Aug 2;45(3):464-8. https://doi.org/10.17159/wsa/2019.v45.i3.6743

Shibambu Chavani Steven was born in Malamulele, Limpopo Province, in

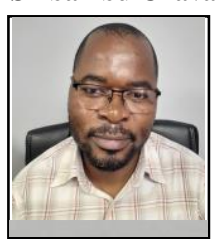
1978 and Matriculated from Shikundu High School in 1997. He obtained Bachelor of Earth Science in hydrology and water resources from the University of Venda, South Africa, in 2003 and Graduated Master of Earth Science in Hydrology and Water Resources from the same university in 2016. He started working as a Water Pollution Control Officer at the Department of Water and Sanitation, South Africa, in 2004 and as a Hydrologist in 2006. He was then appointed as a Scientist Production Grade C in 2009 and was then promoted to a Deputy Director by the same Department in 2014 based in Northern Cape and later moved Mpumalanga where he is currently serving as a Deputy Director: Regional Institutional Oversight. He is the Author of a paper titled Field Study on Heavy Metal Removal in a Natural Wetland Receiving Municipal Sewage Discharge published in the International Journal of Sustainable Development and Planning in 2017.

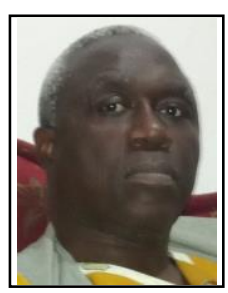

Prof Jabulani Ray Gumbo graduated with a $\mathrm{PhD}$ in Water Resources Management from University of Pretoria in 2007. He was awarded the second-best student poster price at the 12th International Conference on Harmful Algae in 2006 and the study was then published in the prestigious conference proceedings after a rigorous peer review process. This author became a Member (M) of International Society for the Study of Harmful Algae; International Mine Water Association; Water Institute of Southern Africa; Microscopy Society of Southern Africa and South African Council for Natural Scientific Professions. In 2008, he was appointed as a senior lecturer at University of Venda and in 2016 he was appointed as Associate Professor. He is the first or second author of more than 86 research outputs ( 3 patents, 38 peer reviewed papers with more than thirds of these published in international journals with an impact factor; 41 peer reviewed conference proceedings and 3 technical reports and four book chapters). He acts as a reviewer for NRF in the fields of cyanobacteria and has been invited to be a reviewer for scientific committees for international conferences $\&$ journals. 